DOI: https://doi.org/10.31538/ndh.v5i3.984

http://e-journal.ikhac.ac.id/index.php/nidhomulhaq

\title{
TEACHER'S LEADERSHIP TEACHING STRATEGY SUPPORTING STUDENT LEARNING DURING THE COVID-19 DISRUPTION
}

\author{
Aslan $^{\text {1) Silvia }}{ }^{2)}$ Budi Sulistiyo Nugroho ${ }^{3)}$ M. Ramli4) Rusiadi' \\ ${ }^{1}$ Institut Agama Islam Sultan Muhammad Syafiuddin Sambas, Indonesia \\ aslanmarani88@yahoo.com \\ ${ }^{2}$ Sekolah Tinggi Islam Ekonomi Managemen Bisnis. Indonesia \\ silvia.ekasari@stiembi.ac.id \\ ${ }_{3}^{3}$ Politeknik Energi dan Mineral Akamigas (PEM Akamigas), Jawa Tengah, Indonesia \\ nbudi.nugroho@gmail.com \\ ${ }^{4}$ Fakultas Tarbiyah dan Keguruan UIN Antasari Banjarmasin \\ m.ramli66@gmail.com \\ ${ }^{5}$ Institut Agama Islam Sultan Muhammad Syafiuddin Sambas, Indonesia \\ kandarusiadi@gmail.com
}

\begin{abstract}
Abstrak
Paper ini bertujuan untuk meninjau strategi pembelajaran kepemimpinan guru dalam meningkatkan basil belajar siswa sejak pemerintah mengirim siswa pulang untuk memperlambat penyebaran pandemi COVID-19. Keberbasilan belajar siswa selama pandemi terkait erat dengan pemabaman dan penerapan strategi kepemimpinan guru dalam membantu siswa belajar dari rumah. Untuk. mendukung guru dalam keberbasilan belajar siswa, kami telah meninjau literatur, terutama pembelajaran siswa selama penutupan sekolah. Setelah pengumpulan data, kami melanjutkan analisis dan interpretasi mendalam dengan pendekatan deskriptif kualitatif. Analisis dan interpretasi meliputi kompetensi yang ingin dicapai, motivasi belajar, bahan ajar, metode pendampingan, dan rubrik evaluasi keberhasilan. Setelab kami mengbubungkan semua elemen di atas dengan pengajaran, pedagogi, dan pemahaman tentang realitas belajar siswa pada masa pandemi, akbimya kami berbasil menyusun rumusan strategis strategi kepemimpinan guru sebagai berikut: 1) praktik pembelajaran spasial, 2) pendekatan retrospektif, 3) pembelajaran elaboratif praktis, 4) pembelajaran kolaboratif, 5) pendekatan interleaving, 6) komitmen konkret, 7) keterampilan pengkodean ganda, 8) sumber daya yang bermanfaat, 9) kompetensi digital, dan 10) merayakan setiap keberbasilan. Temuan ini valid dan reliabel. Oleh karena itu, temuan ini dapat menjadi strategi kepemimpinan guru untuk mendukung pembelajaran siswa dari rumah saat ini ketika pembelajaran masih dilakukan dengan cara yang berani.
\end{abstract}

Kata Kunci: Kepemimpinan Guru, Strategi Mengajar, Mendukung Siswa, Belajar dari Rumah, dan Krisis COVID-19

Abstract
This project aimed to review teacher's leadership learning strategies in improving student learning outcomes since the government sent students home to slow the spread of the COVID-19 pandemic. The student's learning success during pandemic is closely related to understanding and implementing teacher leadership strategies in helping students learn from home.To support teachers in student learning success, we have reviewed literature, especially student learning during school closings. After data collection, we continued in-depth analysis and interpretation with a descriptive qualitative approach. Analysis and interpretation include the competencies to be achieved, learning motivation, teaching materials, mentoring methods, and success evaluation rubrics. After we connected all the elements above with teaching, pedagogy, and understanding of the realities of student learning during the pandemic, we finally succeeded in compiling a strategic formulation of the teacher leadership strategies as follows: 1) spatial learning practice, 2) retrospective approach, 3) practical elaborative learning, 4) collaborative learning, 5) interleaving approach, 6) concrete commitment, 7) multiple coding skills, 8) helpful resources, 9) digital competence, and 10) celebrating every success. These findings are they are valid and reliable. Therefore, the implication of this findings can be strategy for teachers to back up students learning from home today where teaching still remains in remotely settings.

Keywords: Teacher Leadership, Teaching strategy, Supporting students, Learning from Home, and COVID-19 Crisis 


\section{INTRODUCTION}

Virtual learning is a new method for education in the country, especially at the high school level so that many teachers, students, and even school principals experience stuttering and confusion in carrying out learning from home during the government's policy of repatriating students, in order to reduce and slow down the spread of coronavirus among students in schools throughout Indonesia. (Aditya et al., 2019; Aditya \& Permadi, 2019; Putra et al., 2020). What happened, the teachers were only able to give as many assignments as just spending time, such as asking students to summarize or work on question assignments without any explanation and enrichment by virtual or online learning as intended by distance learning experts during the interruption of COVID-19. Therefore, the solution of Rahmawati \& Hakim, (2017) method can be a consideration for teachers to use virtual learning media E-Learning to improve student outcomes at the secondary school level. Previously, various solutions had also been made to help teachers provide lessons for educators at school closings. The real answers are quite numerous, but most of the solutions they propose are somewhat challenging to understand, let alone implement. So that the closing period continues and students do not get the learning outcomes expected in the curriculum. Because the solutions provided cannot be applied and follow students' methods and needs in learning from home, neither policymakers nor those practices in the field do not fully know and understand the processes, approaches, and strategies that lead to teaching leadership and teacher learning the pandemic.

During the school's closure, the author observes where students are sent home, but the class is still open online. The mass media mentions the current way of learning online or in remote networks. However, what happened was that students carried out task-based learning using smartphones; In fact, the teachers only use the WhatsApp application, send photos of assignments to students, and students also do the same thing when they are ready to do what the teacher instructs even without explanations and examples of practice questions. Concerning this matter, Wargadinata et al. (2020) assessed that student responses to learning problems with the online system during the pandemic were very low for various reasons such as the limitations of many families in providing adequate facilities and the limited ability of teachers to deliver lessons following the demands of the school closing period (Munjiat, 2020). Finally, all teachers keep using the same method, and so on. Until now, no one 
understands why teachers choose to teach through the way. The assignment system is implemented as a way out to overcome some of the limitations that are owned.

Meanwhile, parents and students only receive organizational learning, which schools call the online system. Even though it is only limited to using the WhatsApp application, many teachers cannot learn this method. Not to mention the problem that not all student families can access the Android system and internet signals. What applies today is still very relevant to West, (2013) research, which states that mobile learning has not yet transformed learning innovations. That can involve students and improve results for various reasons and technical fields and basic principles constraints related to the learning media's leadership ability, especially in a country that still operates a traditional education system.

The findings of Malisch et al. (2020) confirm that academics must find new solutions to ensure that every student, especially gender equality and socialeconomic status, is not shackled in learning since the emergence of COVID-19. Through this research for educational researchers and educators, the emergence of a pandemic is not considered a big problem, so it must interfere with student learning activities and safety. On the other hand, according to Kidd \& Murray (2020), the emergence of the Covid-19 pandemic certainly has a significant impact on teachers' ability to help students. To overcome this, they suggested that teachers transform learning, even though the practicum was adequately online. Likewise, teachers in Indonesia must make each student adaptable to the conditions through a strategic and dynamic approach, teacher dedication, and teaching leadership patterns. In this way, teachers must think transformatively and see problems as challenges that always have a solution.

Likewise, every solution must serve as a guide from the results of the assessment to guide teachers appropriately and responsively; The current pandemic condition that continues to disrupt the smooth running of education must find solutions to be shared with teachers with teaching and educational leadership strategies with a design that is right on target and easily explained by teachers. With strategic teaching leadership, teachers will solve all the challenges students face when the pandemic continues to disrupt school children's educational journey. With this study, a summary review of teacher teaching strategies will be recommended to teachers to assist students with a solutionoriented and results-oriented approach by looking at the potential for disruption to 
student learning when school closures in Indonesia require all parties to participate in advance at all costs. (Acer, 2015; Yige, 2019; Dilek, 2015; Gilbert, 2019).

Spillane et al. (2003) said that the teacher's leadership teaching strategy certainly requires reviewing and analyzing its effectiveness and productivity when applied. This study and analysis will undoubtedly be guided by findings in other countries that have experienced the emergence of Covid-19 and various responses from each country when the pandemic occurs in other parts of the world. The specific purpose of this review study is to find a strategic teaching approach for teachers when they have to help students learn when they are sent home by the government to respond to the spread of Covid-19. The principle of this research is to facilitate the teaching process from home by designing several teaching concepts and strategies that are easy for teachers to apply, responsive and adaptive to disruptions in the education of students who live side by side with COVID-19. Flores and Gago (2020) stated that teachers need flexible and sophisticated time COVID-19, where they have to support students with pedagogical responses. So that teachers can protect students from getting the right and opportunity to learn even though the epidemic still lurks them.

\section{METHOD AND MATERIALS}

This paper aimed to identify teacher leadership teaching strategies that could motivate students to enjoy learning at home during Indonesia's pandemic. To make it easier to find the teachingstrategies required in this study, we have collected various literature for initial reading. We then analyze it under the phenomenological approach. Creswell \& Poth (2016) suggest that qualitative review research is an appropriate study to assess educational, social problems such as teacher leadership teaching strategies when helping students learn enthusiastically. To adapt and facilitate this research, we have reviewed documents related to teaching leadership strategies during the pandemic, pedagogy, issues related to the impact of school closures, and the development of the COVID-19 case. To get the finding that content the validity and reliability, we have analyzed and conducted interpretation that answers the research question proposed previously. Besides the rubric's relevance as an assessment of students in distance learning, it is necessary to review the teaching method. That is what convinced us to compile this review. Furthermore, we document it as a teaching guide with high leadership values for 
teachers, especially for all those who are currently facing learning conditions affected by COVID-19, especially teachers who are assigned to fill and teach remotely, which is very challenging, involving skills teaching and flexibility help student learning from home.

\section{DISCUSSION}

This review study's main objective is to find out some leadership and strategic learning approach to suggest to teachers in supporting students learning from home since the school closures impacted by the COVID-19. Here are what we have identified as follows:

\section{Partial learning practice strategy}

With a typical home study, the average student gets distracted by many objects and conditions. So teachers can consider how to apply a visual-spatial strategy approach. This strategy allows students to learn step by step. Visual imagery plays an essential role in the learning process of this approach. Because students can process content in pictures and words, the ideas are interconnected. This approach is right; the answer is that visual-spatial affects learning utilizing learning in the visualspatial area; it does not need understanding like learning methods in classrooms or labs requiring full concentration. For example, students' spatial abilities are used daily at home from navigation, understanding or repairing equipment, understanding or estimating distances and measurements, and doing work. The spatial strategy point is to enable students 'ability to understand, reason, and remember the spatial relationships between learning objects or students' thought spaces.

This review research aimed to convince the Indonesian academic community about the usefulness of the RSD framework, which has become the reference framework for researching the world of higher education in several developed countries. Adhering to the introduction, problem formulation, methods, results, discussion, and discussion of this review's course and flow, we can conclude some simple conclusions. This RSD framework has six research facets, forming a vertical developed at one of Australia's leading universities, namely the University of Adelaide. The framework of this RSD has a horizontal framework describing the level of students' ability to learn and work autonomously. This framework has five levels of student autonomy that are differentiated based on the degree of processing ability and the extent to which the resolution of answers integrates existing student and research understanding and produces new knowledge in RSD-owned rubrics with six research aspects five levels of autonomy. Students move as moving from a low level of independence requires lecturers' 
structure and guidance to a high level of autonomy.

\section{Retrospective learning leadership strategy.}

A learning method with an observational method involves students learning in specific conditions that require students to learn while reflecting backward. Many cases from current conditions such as COVID-19 or specific problems is so relevant. In other words, all cases occur before learning begins. The retrospective is a method of retrieving information related to the past. Teachers can tell stories in the form of events about cases of COVID-19 that have something to do with the future of students so that they have a reason to sit and learn from home. A retrospective study method in which teachers can provide information about the risks will occur if students do not comply with government protocols on COVID-19. Teachers can also discuss ways students take shelter from being exposed to developing outside the home.

The elaboration approach to leadership learning strategy

Cognitive learning involves increasing information that seeks to clarify or add to the relationship between existing information learned and added with related information. With students' experience with previous COVID-19 information presented sequentially, they added that new understanding could be. Elaboration can take the form of coding the original content in different but related ways. This effort accustoms students to be good at communicating by elaborating their thoughts on the situation to discuss. The elaboration method can be in visual and verbal form. For example, to learn a foreign language city pair "cow-boy," students can form a new imagination, visualizing a cow grazing many cows.

\section{The collaborative leadership learning strategy}

An approach or learning procedure for teachers that explicitly helps the learning process in an open, collaborative way is usual for learning with teacher central orientation. When students learn from home, the teacher must choose an approach to academic and social interactions through virtual ways and allow students to plan together with the teacher to learn how to collaborate in pairs, teamwork for a common goal. In other words, collaborative learning is a teaching and learning method in which students work together to explore essential questions or create meaningful projects together with teachers and students as peer learners. It could be in small or large groups of students to share roles in developing social, interpersonal skills. This 
collaborative approach does not differentiate between social status and learning seniority. As long as it can solve cross-social problems, solve problems with concepts, and build a learning community together and in rhythm while studying at home to respond to COVID-19.

\section{The interleaving leadership teaching} approach

Students' learning process uses several subjects while they are learning to improve their learning in distance learning. This teaching type involves studying a topic with great care before moving on to new topics and practice tests of previous discussion exercises. This strategy is most useful for online home learning. So the teacher can choose this method to test whether the students have practiced the theme of cleansing. The interleaving approach is very appropriate for the teacher because it is the opposite of cramming all the topics and exercises in collaboration and explaining what students have practiced during individual learning. Besides, this method encourages repeat relaxing and practicing summarizing what has been discussed independently by each student while learning to respond to COVID-19.

\section{Building a positive learning strategy approach}

a strategy to build a positive relationship between teacher teaching and students and parents. Since COVID-19, where face-to-face school-like relationships are no longer possible, from the first day of distance schooling, teachers should build positive learning relationships with students with each other. With this strategy, teachers can prepare ice-breakers in an online and fun way. Considering that teachers and students cannot like to meet in class, so send news, and as often as possible, each subject teacher contacts students with various possible means. It is very significant and positive. The teacher and students call each other home to establish a positive learning relationship immediately. Of course, this method considers many things, including time, relevant discussion material, online social attitudes, acts of generic relations between teachers and students, instill intrinsic pedagogic motivation, positive role models for teachers, and education-based relationships.

\section{Multiple Coding skills}

Even though coding is used in the computer world's programming language to run as desired, every teacher must understand, be informed, and understand learning in their respective fields. At least 
students understand the new understanding from the teacher. For example, how does each computer coded language tell the computer to do something it wants. At least every teacher is interested in doing a mini-study. How do students proceed alone outside of class? Approach the teacher to impose an understanding of coding with an attractive strategy to perform. It is how teachers can leave sequential tasks that students can learn in any way they like outside of online classes. Through these coding skills, students can express themselves in solving problems in the programmer world. Maybe some students can focus on the application. Maybe some people are interested in programming languages, even if they do not care and practice them now. At least the teacher can start to develop two crucial aspects that will help students in all aspects of life. For all these reasons, teachers must code so that students can improve their own lives.

\section{Useful learning resources}

The purpose of teaching and learning resources are not only to make the educational process more exciting but also to encourage active learning. Because with the development of different skills, the adoption of the values and attitudes that students want in order for them to be successful is an enrichment of materials used to teach students even with a remote system. With these learning resources, it is possible for each lesson activity that is designed to allow students to learn and gain high and broad knowledge. Learning resources will be vital because they can significantly improve student achievement by supporting student learning. In particular, these learning resources will be beneficial in the learning process and allow students to explore knowledge independently and provide more repetition. Educational resources are undoubtedly crucial in the development of a conducive teaching and learning environment. These resources can provide the teacher with a more helpful and powerful direction than any personal effort without material. However, learning resources can include text, software, manuals, videos, and other digital ones, but teacher-based learning resources will certainly have different results. So it is essential that teachers first become learning resources for students even though learning is no longer what it was before the pandemic.

\section{Digital Competency}

Before this digital skill is taught to students, of course, each subject's teacher must have a general understanding of what and why this competency is essential to teach. As understood in simple terms, 
digital is a set of skills, knowledge, and attitudes that enable smart, creative, and critical technology and systems in an increasingly digital world. In other words, this digital competence can mean crucial 21st-century skills for teachers and students and the wider community. This digital competence is essential in learning, work, and active participation in society. Especially when school is in distance learning, this skill is as essential as understanding the competence itself because this is knowing how teachers make these skills into teacher leadership skills in helping students develop them. The essential thing that must be explained by the teacher is to help students identify, find, retrieve, store, and analyze information and data digitally, assessing its relevance and purpose for use. Eventually, students will understand and communicate in a digital environment, share resources, connect with others, collaborate through digital tools, interact with and participate in communities and networks, and show global cross-cultural awareness. That is why teachers must first understand and be highly committed to encouraging students with these modern skills.

\section{Celebrating every student's success}

Acquiring and celebrating student learning success is a high motivator for every student. Why is that because this celebration will reinforce the meaning behind all their hard study? Celebrating such successes shows appreciation for learning achievements even from a distance. In turn, it will increase the students' self-esteem in the teacher's eyes and motivate them to be more motivated to take further steps and success. Celebrating student success is an essential element in every class and throughout each semester. There are many ways teachers and school leadership motivate students by celebrating their achievements in simple, joyous, and inspiring ways to celebrate students and create positive classroom and inter-school communities intentionally. For example, by giving out identity cards, celebrating every month's success, award ceremonies for giving gifts, and publishing every student's work in class and throughout the school positively. It is a form of strategy for teachers who have high leadership qualities to help students learn.

This discussion aims to interpret and describe the importance of teachers' strategies in helping students study at home during the COVID-19 pandemic. In this discussion, we will relate to the theory and previous studies about the importance of asceticism and the close relationship between teacher support and the success of students learning from a distance. So, it 
can explain these findings into new knowledge and understanding for the learning community in Indonesia, which has not been resolved the problem of decreasing student learning output since the school sent students home and studied at home with remote guidance from parents and the teacher council. So finally, this finding is valid and reliable.

The findings of Cao et al. (2020) proves that students received a psychological impact after the COVID-19 pandemic hit China in early exposure of the COVID-19. So, teachers' support is beneficial for students regarding lesson content and factors related to learning, such as mental and mental health, especially for students experiencing the impact, but those who have experienced the loss of family members after being exposed to COVID-19. Meanwhile, in the study conducted by Tran et al. (2020) toward continuing student learning during school closures, students not only need support with study assignments and other means, but they also need socioeconomic, occupational aspirations, and learning behaviors of most Vietnamese students who survived their discharge because of responding to COVID-19. Furthermore, they said that Vietnamese students would drop out of many teachers, and the government did not help students exceed the school's needs but for life necessities.

Next is the study by Bao (2020), which says that COVID-19 and online learning in higher education is much helped by the support of teachers and teams from schools, especially when it comes to changes in attitudes and mental resilience of students when facing an emergency such as students having to carry out heavy assignments without adequate support and facilities. Next, Ferdig et al. (2020) examined teacher support in teaching with the help of technology to help students during the pandemic. They studied the real story from the relationship between teaching during the COVID-19 period and the effectiveness of using remote learning technology.

Another case studied by Rapanta et al. (2020) discusses online university teaching during and after the COVID19 crisis, which needs to refocus on teacher attendance and face-to-face learning activities. Students themselves are required to master the online learning system in modern education. They may not find staff support useful in assisting students during long-distance learning during the pandemic, Not to mention when referring to a study conducted by Aliyyah et al. (2020) regarding the perceptions of elementary school teachers in Indonesia 
towards online learning during the COVID-19 Pandemic Period which states that learning success during COVID-19 is determined by the readiness of teachers to support students.

All of them implied that several teachers were not ready for the collaborative online learning way that the government through dwarves wanted. Closing the discussion of all of our studies, the findings of Pather et al. (2020) on how the attacks on the sustainability of education in Australia and New Zealand have imposed a severe command response through the readiness and support of teachers, primarily to support various techniques and approaches of stakeholders in their countries during the COVID-19 emergency period in less developed countries, Australia.

\section{CONCLUSION}

As mentioned above, this study's primary purpose is to review the literature related to teacher leadership efforts and strategies in supporting students to study at home while being discharged to maintain health from the 2019 coronavirus while continuing education learns from a distance by maximizing existing facilities. After going through in-depth study and discussion, it can be concluded that the teacher's role and support are significant during the learning process from home, which is now almost one year old. Generally, it can be concluded that, among other things, spatial learning practices, retrospective approaches, practical elaborative learning, collaborative learning, interleaving approaches, concrete commitment, multiple coding skills, resource helpful, digital competence, and celebrating every success. These findings are valid and reliable. Therefore, these findings will be an alternative strategy for teachers to support students learning from home while COVID-19 still exists.

\section{REFERENCES}

Acer, D. (2015). The arts in Turkish preschool education. Arts Education Policy Review, 116(1), 43-50.

Aditya, B. R., Nurhas, I., \& Pawlowski, J. (2019). Towards Successful Implementation of a Virtual Classroom for Vocational Higher Education in Indonesia. In $\mathrm{L}$. Uden, D. Liberona, G. Sanchez, \& S. Rodríguez-González (Eds.), Learning Technology for Education Challenges (pp. 151-161). Springer International Publishing. https:/ / doi.org/10.1007/978-3030-20798-4_14

Aditya, B. R., \& Permadi, A. (2019). Gender differences in students'elearning usage outcomes. 2019 5th International Conference on Science and Technology (ICST), 1, 1-5.

Aliyyah, R. R., Rachmadtullah, R., Samsudin, A., Syaodih, E., Nurtanto, M., \& Tambunan, A. R. S. (2020). The Perceptions of Primary School Teachers of Online 
Learning during the COVID-19 Pandemic Period: A Case Study in Indonesia. Journal of Ethnic and Cultural Studies, 7(2), 90-109.

Bao, W. (2020). COVID-19 and online teaching in higher education: A case study of Peking University. Human Behavior and Emerging Technologies, 2(2), 113-115.

Cao, W., Fang, Z., Hou, G., Han, M., Xu, X., Dong, J., \& Zheng, J. (2020). The psychological impact of the COVID-19 epidemic on college students in China. Psychiatry Research, 287, 112934. https://doi.org/10.1016/j.psychres .2020 .112934

Dilek, A. (2015). Okulöncesi Dönem Çocuklarının Sanat Hakkındaki Düşünceleri:'Çocuk Sanatçı-Sanatç1 Çocuk'Projesi. Kastamonu Education Journal, 23(4).

Ferdig, R. E., Baumgartner, E., Hartshorne, R., Kaplan-Rakowski, R., \& Mouza, C. (2020). Teaching, Technology, and Teacher Education during the COVID-19 Pandemic: Stories from the Field. Association for the Advancement of Computing in Education (AACE). https://www.learntechlib.org/p/2 16903/

Gilbert, B. (2019). UnArthodox: An Investigation of How Children Articulate Their Sense of Self through Art.

Kidd, W., \& Murray, J. (2020). The Covid19 pandemic and its effects on teacher education in England: How teacher educators moved practicum learning online. European Journal of Teacher Education, 1-17.

Malisch, J. L., Harris, B. N., Sherrer, S. M., Lewis, K. A., Shepherd, S. L.,
McCarthy, P. C., Spott, J. L., Karam, E. P., Moustaid-Moussa, N., \& Calarco, J. M. (2020). Opinion: In the wake of COVID19, academia needs new solutions to ensure gender equity. Proceedings of the National Academy of Sciences, 117(27), 15378-15381.

Munjiat, S. M. (2020). Implementation of Islamic Religious Education Learning in Higher Education on The Pandemic Period. Nazhruna: Jurnal Pendidikan Islam, 3(2), 285295.

https://doi.org/10.31538/nzh.v3i2 .757

Pather, N., Blyth, P., Chapman, J. A., Dayal, M. R., Flack, N. A., Fogg, Q. A., Green, R. A., Hulme, A. K., Johnson, I. P., \& Meyer, A. J. (2020). Forced Disruption of Anatomy Education in Australia and New Zealand: An Acute Response to the Covid-19 Pandemic. Anatomical Sciences Education, 13(3), 284-300.

Putra, P., Liriwati, F. Y., Tahrim, T., Syafrudin, S., \& Aslan, A. (2020). The Students Learning from Home Experiences during Covid-19 School Closures Policy In Indonesia. Jurnal Iqra': Kajian Ilmu Pendidikan, 5(2), 30-42. https://doi.org/10.25217/ji.v5i2.1 019

Rahmawati, F., \& Hakim, L. (2017). Virtual E-Learning Media to Improve Vocational School Students' Learning Outcome. International Conference on Teacher Training and Education 2017 (ICTTE 2017).

Rapanta, C., Botturi, L., Goodyear, P., Guàrdia, L., \& Koole, M. (2020). 
Online university teaching during and after the Covid-19 crisis: Refocusing teacher presence and learning activity. Postdigital Science and Education, 1-23.

Spillane, J. P., Diamond, J. B., \& Jita, L. (2003). Leading instruction: The distribution of leadership for instruction. Journal of Curriculum Studies, 35(5), 533-543.

Tran, T., Hoang, A.-D., Nguyen, Y.-C., Nguyen, L.-C., Ta, N.-T., Pham, Q.-H., Pham, C.-X., Le, Q.-A., Dinh, V.-H., \& Nguyen, T.-T. (2020). Toward Sustainable Learning during School Suspension: Socioeconomic, Occupational Aspirations, and Learning Behavior of Vietnamese Students during COVID-19. Sustainability, 12(10), 4195.

Wargadinata, W., Maimunah, I., Dewi, E., \& Rofiq, Z. (2020). Student's Responses on Learning in the Early COVID-19 Pandemic. Tadris: Jurnal Keguruan Dan Ilmu Tarbiyah, 5(1), 141-153.

West, D. M. (2013). Mobile learning: Transforming education, engaging students, and improving outcomes. Brookings Policy Report, 9, 1-7.

Yige, M. M. (2019). Visual arts education provisions for primary schools in Turkey. Arts Education Policy Review, 120(1), 11-18. 